\title{
PARTNERSTWO PUBLICZNO-PRYWATNE JAKO STRATEGICZNE WYZWANIE W ZARZĄDZANIU KLASTREM
}

\begin{abstract}
Artykuł koncentruje się na współczesnym podejściu do złożonej i wieloaspektowej problematyki partnerstwa publiczno-prywatnego (PPP) wewnątrz ekosystemu klastra, którego granice są wysoce zmienne. Podstawą zaprezentowanych w artykule rozważań i formułowanych wniosków były nie tylko wyniki badań empirycznych, przeprowadzonych za pomocą metody badań ankietowych na celowo dobranej próbie 28 menedżerów polskich klastrów, ale także analiza literatury przedmiotu i danych zastanych (metoda desk research). Praktyczne podejście do problemu badawczego poparto wybranymi doświadczeniami i dobrymi praktykami klastrów. Artykuł składa się z trzech części, w których scharakteryzowano w sposób syntetyczny istotę i główne założenia koncepcji PPP, jej znaczenie dla rozwoju klasteringu oraz jej postrzeganie przez menedżerów klastrów. Na podstawie analizy literatury przedmiotu wykazano, że sprawne wykorzystanie potencjału PPP stwarza strategiczne wyzwanie przed koordynatorami klastrów m.in. w zakresie kształtowania relacji z partnerami publicznymi i zabezpieczenia źródeł finansowania tego typu projektów. Finansowanie inwestycji ze środków krajowych i zagranicznych może sprzyjać zarówno budowie i modernizacji infrastruktury komunalnej, jak i rozwojowi klastrów. W szczególności projekty hybrydowe, w których formuła PPP dofinansowana jest ze środków Unii Europejskiej, umożliwiają realizację dużych przedsięwzięć infrastrukturalnych, zaspakajających potrzeby społeczne. W tym przypadku instytucjonalny koordynator i członkowie klastra mogą pełnić rolę partnera prywatnego, będącego inwestorem, generalnym wykonawcą lub podwykonawcą. Zaprezentowane w artykule wyniki badań empirycznych dowodzą, że dotychczas w większości badanych klastrów nie realizowano projektów w formule PPP. Pomimo to bardzo optymistyczny jest fakt, że koordynatorzy i członkowie tych klastrów wykazują realne zainteresowanie tego typu partnerstwem strategicznym, chociaż wciąż brakuje sprzyjającego klimatu dla jego implementacji w wielu regionach kraju.
\end{abstract}

Słowa kluczowe: klaster, zarządzanie, partnerstwo publiczno-prywatne, rozwój.

\section{WSTEP}

Współczesne klastry w Polsce jako organizacje celowo zorientowane o różnym stopniu sformalizowania są w znacznej mierze zakorzenione regionalnie. Wykorzystanie ich potencjału dla rozwoju społeczno-gospodarczego jest przedmiotem krajowej i regionalnej poli-

${ }^{1}$ Dr Bogusław Bembenek, Wydział Zarządzania, Politechnika Rzeszowska im. Ignacego Łukasiewicza, Al. Powstańców Warszawy 12, 35-959 Rzeszów, e-mail: bogdanb@prz.edu.pl.

Boguslaw Bembenek, PhD, Rzeszow University of Technology, Faculty of Management, St. Powstancow Warszawy 12, 35-959 Rzeszow; e-mail: bogdanb@prz.edu.pl. 
tyki klastrowej. W ramach tej polityki uzasadnionym i pożądanym kierunkiem wspierania rozwoju klastrów jest dla przykładu zapewnienie odpowiednich warunków dla partnerstwa podmiotów sektora publicznego i prywatnego na rzecz wspólnej realizacji społecznie użytecznych przedsięwzięć i złożonych projektów infrastrukturalnych. Jest to tym bardziej ważne zważywszy na fakt, że w ekosystemie klastrów większość zadań i inwestycji publicznych z zakresu usług użyteczności publicznej może być przedmiotem partnerstwa publiczno-prywatnego. Tym samym sytuacja ta stwarza nowe, strategiczne wyzwanie w zarządzaniu klastrem, gdyż chcąc czerpać obopólne korzyści z implementacji tej formy partnerstwa strategicznego niezbędne jest nie tylko upowszechnienie o niej wiedzy, ale także sprawne wykorzystanie zasobów klastra i koordynowanie klastrowych inwestycji w warunkach turbulentnego otoczenia.

Celem artykułu jest charakterystyka partnerstwa publiczno-prywatnego w klastrze, zarówno z perspektywy teoretycznej, jak i praktycznej. W ramach tak określonego celu podjęto próbę odpowiedzi na następujące pytania badawcze:

- jakie są podstawowe założenia koncepcyjne PPP i uwarunkowania pomyślnej jego implementacji na rzecz sprawnej realizacji inwestycji publicznych w Polsce?

- co świadczy o strategicznym znaczeniu PPP dla rozwoju klastra?

- jak postrzegają menedżerowie polskich klastrów ideę PPP i możliwość jej zastosowania w ekosystemie klastra?

Materiał empiryczny pozyskano w znacznej mierze za pomocą klasycznej i użytecznej metody badań ankietowych. W celowym doborze grupy respondentów (28 menedżerów klastrów) kierowano się ich praktycznym doświadczeniem oraz zakresem i celem badań.

Inspiracji do podjęcia tej złożonej i wieloaspektowej problematyki dostarczyły liczne dyskusje w trakcie konferencji klastrowych, dotychczasowe działania władz publicznych, ukierunkowane na promowanie i stopniowe ograniczanie barier implementacji PPP oraz własne doświadczenia w zakresie badań polskich klastrów. Pomimo rosnącej popularności koncepcji PPP, jak dotąd nie badano jej w kontekście rozwoju klastrów. PPP w klastrach to wciąż nowy obszar badań i słabo ugruntowany w literaturze naukowej. Tym samym zaprezentowane rozważania mogą stanowić przyczynek do szerszej refleksji nad istotą PPP w klastrach i do rozwoju wiedzy w tym obszarze.

\section{ISTOTA PARTNERSTWA PUBLICZNO-PRYWATNEGO}

Klasyczna koncepcja partnerstwa publiczno-prywatnego, która dotyczy sposobu i zasad realizacji zadań publicznych we współpracy z partnerem prywatnym, wciąż ewoluuje wraz z rosnącymi oczekiwaniami kluczowych interesariuszy, chociażby odnośnie poprawy usług publicznych pod względem jakościowym i ilościowym. Jak dotąd nie wypracowano jednolitej definicji PPP. W literaturze przedmiotu złożone pojęcie partnerstwa publiczno-prywatnego traktowane jest najczęściej jako²:

${ }^{2}$ B. Korbus, T. Srokosz, M. Wawrzyniak, Partnerstwo publiczno-prywatne: poradnik, Warszawa 2010, s. 21; M. Kołodziej-Hajdo, Partnerstwo publiczno-prywatne jako narzędzie nowoczesnego zarzadzania organizacjami publicznymi, „Studia Ekonomiczne. Zeszyty Naukowe Uniwersytetu Ekonomicznego w Katowicach" 2015, nr 224, s. 52; E. Sikora, Partnerstwo publiczno-prywatne w zarzadzaniu Gmina Bytom, „Zeszyty Naukowe Politechniki Częstochowskiej. Zarządzanie” 2017 , nr 25, t. 2, s. 157; A. Paczoski, Reguty oraz znaczenie partnerstwa publiczno-prywatnego dla funkcjonowania przedsiębiorstw, „Zarządzanie i Finanse” 2012, nr 1, t. 10, cz. 3, s. 33; 
- cała sfera współdziałania sektora publicznego z prywatnym w ujęciu doktryny funkcjonowania państwa, gospodarki i społeczeństwa, jak i w ujęciu działań organizatorskich, ukierunkowanych na osiągnięcie określonych celów;

- konkretne typy umów pomiędzy władzą publiczną a podmiotem prywatnym, związane z realizacją przedsięwzięcia inwestycyjnego;

- długofalowa współpraca pomiędzy sektorem publicznym a prywatnym, która stanowi przykład nowoczesnego zarządzania w organizacjach publicznych;

- użyteczny instrument umożliwiający szybszą i efektywniejszą realizację przedsięwzięć związanych z zadaniami sektora publicznego;

- forma finansowania inwestycji infrastrukturalnych, które są niezbędne do sprawnej realizacji zadań publicznych;

- zinstytucjonalizowana współpraca strategiczna pomiędzy wybranymi podmiotami sektora prywatnego i publicznego;

- metoda realizacji zadań publicznych przez organizacje publiczne we współpracy z partnerami prywatnymi;

- efektywny model zarządzania budżetem organizacji publicznych, w tym samorządów, funkcjonujących w turbulentnym otoczeniu.

Te i inne definicje znane z teorii i praktyki gospodarczej wskazują, że PPP jest zazwyczaj traktowane jako nowatorska i niestandardowa forma finansowania zadań publicznych, a zarazem środek zaradczy (remedium) na niewystarczające zasoby publiczne przeznaczane na realizację konkretnych inwestycji ${ }^{3}$. Ponadto podkreślają fakt, że jest to proces długotrwały, przynoszący zamierzone efekty dopiero po kilku latach.

Istotą PPP jest dobrowolność zaangażowania, długotrwała relacja, wspólna odpowiedzialność, podział kompetencji i ryzyka, gdzie sektor publiczny koncentruje się przede wszystkim na celu wspólnego przedsięwzięcia, a nie na metodach jego realizacji ${ }^{4}$. Wraz z rozwojem PPP tworzy się swoista sieć hierarchiczna, w której partner publiczny przejmuje pozycję dominującą i narzuca $\mathrm{w}$ różnym stopniu warunki współpracy swoim partnerom prywatnym, w tym także ich kooperantom ${ }^{5}$.

W Polsce koncepcja partnerstwa publiczno-prywatnego (PPP) uregulowana jest ustawą z dnia 5 lipca 2018 roku o zmianie ustawy o partnerstwie publiczno-prywatnym oraz niektórych innych ustaw ${ }^{6}$. W myśl tej ustawy PPP polega na wspólnej realizacji przedsięwzięcia, opartego na podziale zadań i ryzyk pomiędzy podmiotem publicznym i partnerem prywatnym. Przed wszczęciem postępowania w sprawie wyboru partnera prywatnego podmiot publiczny sporządza ocenę efektywności realizacji danego przedsięwzięcia w formule PPP

B. Włodarczyk, Ekonomiczne $i$ prawne bariery rozwoju partnerstwa publiczno-prywatnego w Polsce, „Optimum. Studia Ekonomiczne” 2013, nr 1 (61), s. 106; M. Kania, Partnerstwo publiczno-prywatne jako forma realizacji zadań jednostek samorzadu terytorialnego, ,Zeszyty Myszkowskie" 2015, nr 2, s. 92.

${ }^{3}$ E. Płaczek, Rozwój logistyki społecznej poprzez partnerstwo publiczno-prywatne, ,Zeszyty Naukowe Politechniki Częstochowskiej. Zarządzanie" 2017, nr 25, t. 2, s. 148.

${ }^{4}$ B. Augustyńska, Koncepcja partnerstwa publiczno-prywatnego na przykładzie Holandii, ,Zarządzanie Publiczne" 2007, nr 3, s. 145.

5 P. Blicharz, S. Skowron, Kapitat intelektualny jako czynnik rozwoju partnerstwa publiczno-prywatnego, Politechnika Lubelska, Lublin 2013, s. 65.

${ }^{6}$ Dz.U. z 2018 r., poz. 1693 
(z uwzględnieniem m.in. kosztów, podziału zadań i ryzyk, cyklu życia przedsięwzięcia) w porównaniu do efektywności jego realizacji w inny sposób, w szczególności przy wykorzystaniu wyłącznie środków publicznych ${ }^{7}$.

Wdrożone zmiany w wyniku nowelizacji ustawy z 2008 roku o partnerstwie publiczno-prywatnym ${ }^{8}$, które w sposób bezpośredni odnoszą się do Strategii na rzecz Odpowiedzialnego Rozwoju, mają przyczynić się do poprawy efektywności wydatkowania środków publicznych i zwiększenia poziomu zaangażowania kapitału prywatnego w realizację inwestycji publicznych, przy sprawnym wykorzystaniu wiedzy oraz kompetencji sektora prywatnego. Zgodnie z nowym stanem prawnym każdy podmiot publiczny może zwrócić się do Ministerstwa Inwestycji i Rozwoju z wnioskiem o zbadanie realności i efektywności planowanego projektu w formule PPP (tzw. certyfikacja). Ponadto najważniejsze rozwiązania w zakresie PPP dotyczą m.in. ${ }^{9}$ :

- możliwości realizacji projektów PPP przez spółkę córkę partnera prywatnego, która nie uczestniczyła w przetargu;

- możliwości udzielania przez samorządy dotacji celowych dla partnerów prywatnych na finansowanie lub dofinansowanie inwestycji związanych z realizacją zadań samorządowych (dotychczas takie dotacje dopuszczalne były tylko dla podmiotów niedziałających dla zysku);

- monitoringu rynku PPP.

Pomyślna implementacja PPP nie jest łatwym zadaniem. Wymaga od partnerów, tj. organizacji publicznych i komercyjnych, holistycznego spojrzenia nie tylko na aktualne i przyszłe uwarunkowania polityczno-prawne, ekonomiczne, społeczne, technologiczne i ekologiczne, ale także na ich wewnętrzny potencjał strategiczny. Wybór takiego sposobu realizacji inwestycji musi być poparty konkretnymi argumentami oraz pełną świadomością procedury wyboru partnera i zawarcia z nim umowy o współpracy. Sprawnie prowadzone negocjacje pozwalają obu stronom sprecyzować przedmiot współpracy, podział zadań i ryzyka, co kształtuje jakość ich relacji i kapitał zaufania ${ }^{10}$. K. Brzozowska podkreśla, że zastosowanie PPP jako sposobu rozwiązywania problemów niedoboru infrastruktury i usług infrastrukturalnych w warunkach turbulentnego otoczenia, w tym dynamicznych zmian techniczno-technologicznych oraz niedoboru środków publicznych na finansowanie nowych i/lub modernizowania istniejących obiektów, wymaga ${ }^{11}$ :

- przekonania lokalnych społeczności o zasadności zaangażowania wybranych organizacji komercyjnych jako partnerów prywatnych w sferę publiczną dla stworzenia klimatu sprzyjającego innowacyjnym rozwiązaniom w zarządzaniu publicznym;

7 Ustawa z dnia 5 lipca 2018 r. o zmianie ustawy o partnerstwie publiczno-prywatnym oraz niektórych innych ustaw.

8 Ustawa z dnia 19 grudnia 2008 r. o partnerstwie publiczno-prywatnym, Dz.U.2009, nr 19, poz. 100 .

9 https://www.miir.gov.pl/strony/aktualnosci/sejm-przyjal-nowelizacje-ustawy-o-ppp (dostęp: 20.08.2018 r.)

${ }^{10} \mathrm{H}$. Nowicki, P. Nowicki, Partnerstwo publiczno-prywatne jako element systemu zamówień publicznych, "Studia BAS" 2014, nr 3 (39), s. 88.

${ }^{11} \mathrm{~K}$. Brzozowska, Innowacyjność partnerstwa publiczno-prywatnego $w$ polityce inwestycyjnej jednostek sektora publicznego w Polsce, „Folia Pomeranae Universitatis Technologiae Stetinensis. Oeconomica” 2011, nr 291 (65), s. 23. 
- przekonania organizacji publicznych, że nawiązana współpraca z partnerami prywatnymi przyczyni się do zadowolenia społeczeństwa z finalnych jej efektów;

- zaangażowania partnerów na rzecz realizacji wspólnego przedsięwzięcia;

- stałego zachęcania do współpracy partnerów prywatnych przez organizacje publiczne m.in. w drodze zapewnienia odpowiedniego poziomu zwrotu z inwestycji oraz stabilnych regulacji prawnych.

Unia Europejska promuje i rozpowszechnia wiedzę o PPP jako innowacyjnym i efektywnym sposobie realizacji projektów rozwojowych. Wspiera hybrydowe PPP, w ramach którego uzupełnieniem finansowania prywatnego są środki pochodzące z funduszy strukturalnych i Funduszu Spójności. Tego typu projekty są szczególnie interesujące dla tych partnerów prywatnych, którzy są beneficjentami finansowych środków unijnych ${ }^{12}$.

Chociaż PPP może być wdrożone w wielu różnych obszarach, to jego potencjał w Polsce wciąż nie jest w pełni wykorzystany. Inwestycje realizowane w tej formule wymagały jak dotąd pokonywania barier mentalnych, organizacyjnych i formalno-prawnych, które związane były chociażby z niskim poziomem wiedzy odnośnie do PPP i zasad realizacji inwestycji, atmosferą nieufności w relacjach organizacji komercyjnych z organizacjami publicznymi, negatywnym postrzeganiem PPP jako narzędzia korupcjogennego, restrykcyjnymi przepisami prawnymi, biurokracją, zobowiązaniami finansowymi, czy też brakiem docelowej strategii rozwoju infrastruktury kraju, w tym w oparciu o kapitał prywatny ${ }^{13}$. W szczególności opory natury psychologicznej ograniczają rozwój PPP i są bardzo trudne do przezwyciężenia ${ }^{14}$. Nie bez znaczenia jest także słabe przygotowanie praktyczne organizacji publicznych do wykorzystania potencjału tej kompleksowej metody realizacji zadań publicznych ${ }^{15}$. Organizacje komercyjne często usprawiedliwiają swój niski poziom zainteresowania PPP nie tylko barierami formalno-prawnymi, ale też brakiem konkretnych projektów, wartych ich zaangażowania i nakładów inwestycyjnych ${ }^{16}$.

Aby skutecznie pobudzić przedsiębiorców do większego zainteresowania się PPP konieczne są m.in. takie działania jak: poprawa jakości współpracy publiczno-prywatnej, rozwój kapitału społecznego, stworzenie systemu amortyzacji ryzyka finansowego projektów PPP (subwencje publiczne finansujące część kosztów inwestycji lub przygotowania projektu), opracowanie regionalnej i krajowej polityki rozwoju PPP oraz stworzenie instytucji certyfikującej wybór formuły PPP przy realizacji projektów inwestycyjnych ${ }^{17}$. Regulacje sankcjonujące ten typ partnerstwa zawierać muszą proste i czytelne ramy zasad, na podstawie których będzie ono realizowane. System regulacyjny powinien wspierać i ułatwiać

12 J. Szafran, Projekty hybrydowe - montaż partnerstwa publiczno-prywatnego i funduszy Unii Europejskiej w projektach rozwoju lokalnego i regionalnego, ,Barometr Regionalny” 2017, nr 4 (15), s. 93.

${ }^{13}$ K. Brzozowska, Innowacyjność partnerstwa..., s. 26.

${ }_{14}$ N. Derlukiewicz, A. Mempel-Śnieżyk, Realizacja inwestycji w formie partnerstwa publiczno-prywatnego - aspekt teoretyczny, „Prace Naukowe Uniwersytetu Ekonomicznego we Wrocławiu” 2016, nr 443, s. 53.

15 M. Kania, Partnerstwo publiczno-prywatne..., s. 95.

16 J. Łukomska-Szarek, M. Włóka, Partnerstwo publiczno-prywatne w procesie rozwoju samorządów lokalnych, ,Zeszyty Naukowe Uniwersytetu Szczecińskiego. Finanse, Rynki Finansowe, Ubezpieczenia" 2014, nr 804 (67), s. 832.

17 Ł. Bernatowicz, Partnerstwo publiczno-prywatne z punktu widzenia doświadczeń strony prywat$n e j$, , Studia BAS” 2014, nr 3 (39), s. 230. 
podejmowane działania przez partnerów, a nie stwarzać im niepotrzebne i trudne do spełnienia wymogi prawne ${ }^{18}$.

Według Ministerstwa Inwestycji i Rozwoju w Polsce od 2009 do 2018 roku zawarto w sumie 126 umów PPP, zróżnicowanych ze względu na status realizacji, model wynagradzania i podstawę prawną wyboru partnera prywatnego ${ }^{19}$. Spośród tych 126 umów 20 z nich już wygasło na skutek spełnienia wzajemnych świadczeń partnerów. Pod względem liczby zawartych i realizowanych umów przodują sektory efektywności energetycznej, sportu i turystyki oraz infrastruktury transportowej. Aktywność organizacji publicznych (głównie gmin miejskich i wiejskich) w zakresie PPP determinowana jest w znacznej mierze zakresem inwestycji publicznych (zwłaszcza samorządowych), poziomem długu publicznego i dynamiką absorpcji unijnych dotacji ${ }^{20}$.

Z uwagi na strategiczne znaczenie PPP dla gospodarki kraju w lipcu 2017 roku Rada Ministrów podjęła decyzję o realizacji polityki na rzecz rozwoju partnerstwa publiczno-prywatnego. W tym kontekście stwierdzono dla przykładu, że ${ }^{21}$ :

- PPP stwarza realną szansę na szybszy rozwój kraju, którą należy wykorzystać i traktować jako alternatywną metodą realizacji zadań publicznych, równoważną z tradycyjnymi metodami w tym obszarze;

- PPP może być realizowane w oparciu o umowę (tzw. kontraktowe PPP) lub stworzoną w tym celu spółkę (tzw. instytucjonalne PPP);

- niezbędne jest większe zaangażowanie środków prywatnych do realizacji inwestycji i świadczenia usług publicznych, gdyż budżety jednostek publicznych, w tym budżet państwa, nie dysponują wystarczającymi środkami finansowymi, które pozwoliłyby na realizację wymaganych przedsięwzięć w obszarze infrastruktury gospodarczej i społecznej;

- niezbędne jest wpieranie jednostek samorządu terytorialnego w realizacji projektów PPP, gdyż ich realizacja w poszczególnych regionach kraju może mieć pozytywny wpływ na rozwój regionalny, w tym zwiększenie liczby i wartości inwestycji, rozwój lokalnej przedsiębiorczości i tworzenie nowych miejsc pracy;

- długość trwania PPP nie może być krótsza niż okres zwrotu nakładów partnera prywatnego (najczęściej 10-30 lat);

- wybór partnera prywatnego powinien być transparentny z wykorzystaniem otwartej procedury przetargowej, uwzględniający jego wiedzę, doświadczenie, innowacyjność, jakość i kreatywność proponowanych rozwiązań;

- podstawowymi miernikami, które pozwolą ocenić efektywność różnorodnych działań publicznych na rzecz rozwoju PPP w kraju do 2020 roku są np.: wzrost liczby realizowanych inwestycji (co najmniej 100 nowych umów), wzrost udziału wartości tego typu umów w nakładach inwestycyjnych w gospodarce (do poziomu 5\%).

Należy podkreślić, że wdrażaniu tej polityki sprzyja projekt „Rozwój partnerstwa publiczno-prywatnego w Polsce”, współfinansowany ze środków Europejskiego Funduszu

\footnotetext{
18 A. Paczoski, Reguty oraz znaczenie partnerstwa..., s. 46.

19 https://www.ppp.gov.pl/baza/Strony/baza_projektow_ppp.aspx (dostęp: 20.08.2018 r.).

${ }^{20}$ K. Szymański, B. Korbus, Analiza rynku PPP za okres od 2009 roku do 30 czerwca 2018 roku, Warszawa 2018, s. 10-18.

${ }^{21}$ Uchwała nr 116/2017 Rady Ministrów z dnia 26 lipca 2017 roku w sprawie przyjęcia dokumentu „Polityka Rządu w zakresie rozwoju partnerstwa publiczno-prywatnego”.
} 
Społecznego (wartość projektu: 10954 690, 47 zł, przypadająca na okres 1.06 .2016 r. 30.11.2019 r.), realizowany przez Ministerstwo Inwestycji i Rozwoju we współpracy z Konfederacją Lewiatan, Fundacją Centrum Partnerstwa Publiczno-Prywatnego, Związkiem Miast Polskich i Związkiem Powiatów Polskich. Jego głównym celem jest podniesienie kwalifikacji pracowników administracji publicznej (jednostek samorządu terytorialnego, administracji rządowej, urzędów centralnych i kontrolnych) w zakresie PPP. Planowane kluczowe finalne efekty projektu to m.in.: co najmniej 1400 uczestników szkoleń/warsztatów, co najmniej 5 wspartych przedsięwzięć PPP na etapie przygotowania kompleksowych analiz przedrealizacyjnych, co najmniej 15 publikacji w zakresie PPP, co najmniej 30 wydarzeń gospodarczych, ukierunkowanych na promocję $\mathrm{PPP}^{22}$.

\section{PARTNERSTWO PUBLICZNO-PRYWATNE W KLASTRACH}

Pomimo dynamicznie rozwijającej się wiedzy z zakresu klasteringu na całym świecie, wciąż trudno w sposób jednoznaczny zdefiniować i opisać istotę PPP w klastrach. W polskiej rzeczywistości gospodarczej nie ma w tej kwestii jednolitego poglądu. PPP wpisuje się bezpośrednio w koncepcję klasteringu, o czym świadczy chociażby wspólnota działań sektora publicznego i prywatnego. Z kolei klastry traktuje się jako skuteczne narzędzie poprawy konkurencyjności gospodarki na poziomie krajowym, regionalnym i lokalnym. Obecność struktur klastrowych w gospodarce zwiększa jej różnorodność strukturalną i instytucjonalną, przez co zyskuje ona większą elastyczność w burzliwym otoczeniu. Tym samym determinuje poziom rozwoju gospodarki, wskazuje na jej potencjał strategiczny oraz dalsze perspektywy rozwojowe ${ }^{23}$.

PPP może być realizowane w różnych formach i modelach na poziomie zarówno całego klastra, jak i poszczególnych jego członków. Dla przykładu stroną tego typu partnerstwa może być instytucjonalny koordynator klastra ${ }^{24}$ lub konsorcjum firm klastrowych. $\mathrm{Z}$ teoretycznego i praktycznego punktu widzenia rozwój klastrów wymaga rozbudowanego PPP, gdzie liderami powinny być podmioty prywatne ${ }^{25}$. Rolą partnera prywatnego jest z reguły wspóffinansowanie danego przedsięwzięcia, określenie jego ostatecznego kształtu technicznego (projektowanie), realizacja (budowa), eksploatacja i utrzymanie powstałej w ten sposób infrastruktury, w celu świadczenia usług użyteczności publicznej lub także usług dodatkowych (komercyjnych ${ }^{26}$. Z kolei partnerzy publiczni, szczególnie w ramach polityki klastrowej, powinni zapraszać koordynatorów i członków klastrów do wspólnej realizacji publicznych inwestycji infrastrukturalno-rozwojowych. Pomyślnie wdrażana koncepcja

${ }^{22}$ https://www.ppp.gov.pl/projekt-rozwoju-PPP/Strony/Oprojekcie.aspx (dostęp: 20.08.2018 r.).

${ }^{23}$ M. Bucka, Wsparcie rozwoju klastrów w Polsce w perspektywie finansowej 2014-2020, „Prace Naukowe Uniwersytetu Ekonomicznego we Wrocławiu" 2017, nr 466, s. 63; A. Tuziak, Klastry jako stymulatory rozwoju regionalnego, ,Nierówności Społeczne a Wzrost Gospodarczy” 2018, nr 54 (2), s. 444.

${ }^{24}$ Zazwyczaj instytucjonalny koordynator klastra zatrudnia menedżera, zajmującego się zarządzaniem klastrem.

25 A. Piątyszek-Pych, Rola samorzadu terytorialnego w realizacji polityki rozwoju opartej na klastrach, ,Zeszyty Naukowe Uniwersytetu Szczecińskiego. Finanse, Rynki Finansowe, Ubezpieczenia" 2013, nr 786 (64/2), s. 157.

${ }^{26}$ D. Zalewski, PPP z wykorzystaniem środków krajowych, „Biuletyn Partnerstwa Publiczno-Prywatnego" 2018, nr 4, s. 41. 
PPP w polskiej rzeczywistości gospodarczej i związane z nią dobre praktyki mogą być zachętą zarówno dla partnerów prywatnych, jak i publicznych, a zarazem potwierdzać, że taka forma realizacji projektów rozwojowych i infrastrukturalnych jest skuteczna i bezpieczna dla partnerów ${ }^{27}$.

Z uwagi na fakt, że PPP może być realizowane w wielu obszarach gospodarki publicznej, tym samym może stanowić źródło wymiernych korzyści nie tylko dla interesariuszy wewnętrznych klastra, ale również zewnętrznych, w tym dla społeczeństwa, które jest finalnym użytkownikiem efektów tego typu partnerstwa (tabela 1). PPP jest niezwykle przydatne dla rozwoju klastrów, w tym wzmocnienia ich łańcuchów wartości ${ }^{28}$. Przejawia się to chociażby w budowaniu sieci i mikrosieci gospodarczych, w których organizacja publiczna współpracując z głównym partnerem prywatnym, pośrednio wchodzi w relacje z jego kooperantami ${ }^{29}$. Należy podkreślić, że poprzez tego typu działania członkowie klastra otrzymują nową szansę na rozwój, m.in. włączając się w realizację większych przedsięwzięć w roli kooperantów. W ten sposób w szczególności mikro, małe i średnie firmy klastrowe mają realną możliwość rozwoju kapitału relacyjnego, wzmocnienia pozytywnego wizerunku i wartości marki, czy też pozyskania cennego doświadczenia ${ }^{30}$.

Złożona sieć relacji szerokiego grona partnerów, reprezentujących sektor biznesu, nauki i otoczenia biznesu w ramach PPP w ekosystemie klastra może poprawić efektywność i produktywność klastra ${ }^{31}$. Bliskość geograficzna, kulturowa, organizacyjna, technologiczna, która stanowi integralny atrybut klastra, sprzyja bowiem specjalizacji, organizacyjnemu uczeniu się, dyfuzji wiedzy i innowacji, wzmacniając sieć relacji kooperantów. Nie sposób nie zauważyć, że każdy z partnerów posiada określone mocne strony, które odpowiednio połączone mogą wyzwolić efekt synergii i służyć realizacji przedsięwzięć publicznych o wysokim standardzie i szerokiej dostępności dla interesu publicznego. Wzajemne przenikanie się wiedzy, doświadczenia i kapitału w relacjach partnerów publicznych i prywatnych w klastrze może sprzyjać nowym inicjatywom rozwojowym, powstawaniu firm odpryskowych i startupów oraz nowych miejsc pracy.

${ }^{27}$ K. Bodzoń, Funkcjonowanie partnerstwa publiczno-prywatnego $w$ ramach realizacji projektów inwestycyjnych, „Przegląd Administracji Publicznej” 2013, nr 1, s. 6, 18.

28 A. Lisowska, Sz. Rubisz, Sektor instytucji publicznych a rozwój klastrów w województwie opolskim, Opole 2011, s. 25.

${ }^{29}$ A. Borowiec, Możliwości budowy sieci gospodarczych na bazie partnerstwa publiczno-prywatnego $w$ świetle badań empirycznych, ,Zeszyty Naukowe Uniwersytetu Szczecińskiego. Finanse, Rynki Finansowe, Ubezpieczenia” 2011, nr 687 (48), s. 46.

30 T. Skica, U. Dzyuma-Zaremba, J. Hady, Klastry w polityce regionalnej, „Barometr Regionalny” 2015, nr 2 (13), s. 49.

31 Ekosystem klastra, który ukształtowany jest głównie w wyniku sieci różnego rodzaju relacji jego członków, wykazuje wpływ nie tylko na samych członków, ale także na interesariuszy zewnętrznych. Jest postrzegany jako miejsce lub sposobność pozyskania korzyści wynikających m.in. z ekonomii skali, zasięgu, elastyczności i synergii. Zob. L. Knop, Zarzadzanie klastrem: koncepcje, strategie, modele, Gliwice 2013, s. 11, 140. Według B. Spigela i R. Harrisona przedsiębiorczy ekosystem klastra opiera się na trzech podstawowych zasadach teorii klastrów, tj. fizycznej bliskości pomiędzy członkami, obecności firm z tego samego sektora i sektorów pokrewnych oraz sprawnym wykorzystywaniu zasobów wiedzy (wewnętrznej i zewnętrznej). Zob. B. Spigel, R. Harrison, Toward a process theory of entrepreneurial ecosystems, „Strategic Entrepreneurship Journal” 2018, nr 12, s. 154. 
Tabela 1. Potencjalne korzyści z realizacji PPP w ekosystemie klastra

\begin{tabular}{|c|l|}
\hline Lp. & \multicolumn{1}{c|}{ Wybrane korzyści } \\
\hline K1 & $\begin{array}{l}\text { Partnerzy poprzez podział zadań, odpowiedzialności i ryzyka zajmują się tą częścią } \\
\text { wspólnego zadania, którą wykonują najlepiej. }\end{array}$ \\
\hline K2 & $\begin{array}{l}\text { Partnerzy dysponują komplementarnym potencjałem, którego wartość poprzez PPP może } \\
\text { być wielokrotnie zwiększona. }\end{array}$ \\
\hline K3 & $\begin{array}{l}\text { Realizacja złożonych przedsięwzięć infrastrukturalnych, wymagających wysokich nakła- } \\
\text { dów finansowych i generujących odpowiednią stopę zwrotu sprzyja sprawnemu wykorzy- } \\
\text { staniu wiedzy, kompetencji i doświadczenia partnerów. }\end{array}$ \\
\hline K4 & $\begin{array}{l}\text { PPP może przyczynić się do wzrostu efektywności wykorzystania funduszy unijnych po- } \\
\text { przez realizację projektów hybrydowych łączących środki publiczne z prywatnymi. }\end{array}$ \\
\hline K5 & $\begin{array}{l}\text { Poziom jakości usług w ramach PPP jest często wyższy w porównaniu do poziomu usług } \\
\text { w ramach tradycyjnego zamówienia publicznego, co wynika z organizacyjnego uczenia } \\
\text { się, integracji działań, innowacji oraz systemu zachęt i kar określonych w umowie PPP. }\end{array}$ \\
\hline K6 & $\begin{array}{l}\text { Inwestycje w formule PPP są zazwyczaj bardziej innowacyjne, a przy tym realizowane } \\
\text { szybciej i taniej niż typowe inwestycje sektora publicznego. }\end{array}$ \\
\hline K7 & $\begin{array}{l}\text { Podmioty prywatne mają możliwość generowania korzyści za sprawą stabilnych źródeł } \\
\text { dochodu w ramach wieloletnich umów z partnerem publicznym, pozwalających na dłu- } \\
\text { gofalowe planowanie działalności biznesowej. }\end{array}$ \\
\hline K8 & $\begin{array}{l}\text { Partner publiczny jest gwarantem potencjalnego zysku dla zaangażowanego partnera pry- } \\
\text { watnego w zakresie realizacji projektu inwestycyjnego. }\end{array}$ \\
\hline K9 & $\begin{array}{l}\text { Partner prywatny zdobywa wiedzę i doświadczenie w obszarze kontraktów publicznych } \\
\text { i aplikowania o dofinansowanie ze środków Unii Europejskiej. }\end{array}$ \\
\hline K10 & $\begin{array}{l}\text { PPP jako forma finansowania przedsięwzięć rozwojowych i innowacji społecznych może } \\
\text { sprzyjać zaspakajaniu potrzeb społecznych, w tym poprawie jakości życia. }\end{array}$ \\
\hline
\end{tabular}

Źródło: opracowanie własne na podstawie: B. Korbus, T. Srokosz, M. Wawrzyniak, Partnerstwo publiczno-prywatne..., s. 23; A. Paczoski, Reguty oraz znaczenie partnerstwa ..., s. 45; K. Borowski, Dotychczasowe doświadczenia i możliwości implementacji partnerstwa publiczno-prywatnego przez jednostki samorzadu terytorialnego w Polsce, „Ekonomiczne Problemy Usług” 2016, nr 125, s. 90; D. Hajdys, Uwarunkowania partnerstwa publiczno-prywatnego w finansowaniu inwestycji jednostek samorzadu terytorialnego, Łódź 2013, s. 112; A. Smalec, Znaczenie partnerstwa publiczno-prywatnego dla rozwoju regionu, ,Zeszyty Naukowe Uniwersytetu Szczecińskiego. Ekonomiczne Problemy Usług” 2011, nr 682 (76), s. 235.

PPP może być zastosowane w ramach realizacji nie tylko dużych inwestycji infrastrukturalnych, ale również mniejszych i lokalnych przedsięwzięć samorządowych ${ }^{32}$. Jednostki samorządu terytorialnego odpowiadają m.in. za budowę i utrzymanie infrastruktury technicznej. PPP pozwala samorządom na dość szybką poprawę stanu infrastruktury bez konieczności zwiększania długu publicznego, w zamian za rozłożenie w czasie płatności na rzecz wykonawcy projektu, klasyfikowanych jako wydatki bieżące ${ }^{33}$.

${ }^{32}$ M. Kania, Partnerstwo publiczno-prywatne..., s. 94.

33 J. Śmiechowicz, Partnerstwo publiczno-prywatne $w$ sektorze dróg - ocena dotychczasowych doświadczeń i możliwości implementacji przez samorzad terytorialny w Polsce, „Prace Naukowe Uniwersytetu Ekonomicznego we Wrocławiu” 2015, nr 404, s. 308. 
Obserwując dotychczasowy poziom zaangażowania jednostek samorządu terytorialnego w rozwój przedsiębiorczego ekosystemu klastrów, spodziewać się można wzrostu ich zainteresowania PPP, gdyż tego typu partnerstwo strategiczne może ${ }^{34}$ :

- być gwarancją stabilnego rozwoju gospodarczego wobec coraz większych trudności związanych z pozyskiwaniem kapitału;

- stymulować sprawne zarządzanie w sektorze publicznym;

- zaspokajać potrzeby w zakresie dostarczania dóbr i usług publicznych;

- kształtować konkurencyjność regionalną.

W warunkach turbulentnego otoczenia, w tym zmian mechanizmów funkcjonowania współczesnej gospodarki PPP ma istotne znaczenie dla podnoszenia konkurencyjności i innowacyjności regionalnej, w tym zwiększania szans rozwojowych poszczególnych regionów. Upowszechnienie dobrych praktyk w tym zakresie może stanowić punkt odniesienia i źródło inspiracji dla krajowych i zagranicznych klastrów.

Omawiając zjawisko PPP z perspektywy klastrów, nie sposób nie odwołać się do praktyki zarządzania klastrem. Aby zilustrować wiedzę teoretyczną, w tym obszarze, konkretnymi doświadczeniami klastrów w Polsce skorzystano z ogólnodostępnych, lecz bardzo znikomych informacji zamieszczonych na stronach internetowych klastrów. Z uzyskanych w ten sposób informacji wynika, że koordynatorzy i członkowie klastrów w różnym stopniu wykazują zainteresowanie rozwojem wiedzy i praktycznych umiejętności w zakresie implementacji PPP. Dla Przykładu w Klastrze Aktywnej Turystyki ${ }^{35}$ w 2017 roku zrealizowano projekt pn. „Partnerstwo publiczno-prywatne szansą na rozwój małopolskiej turystyki”, dofinansowany ze środków Ministerstwa Sportu i Turystyki ${ }^{36}$. W ramach projektu zorganizowano wizyty studyjne dla członków klastra (przedsiębiorców, przedstawicieli jednostek samorządu terytorialnego oraz organizacji pozarządowych) w obiektach turystycznych, które powstały w efekcie PPP. W trakcie wizyt odbywały się warsztaty z udzia-

${ }^{34}$ Partnerzy prywatni zainteresowani PPP powinni inspirować organizacje publiczne w zakresie dobrych praktyk i rozwiązań znanych w biznesie, korzystać z różnych form rozwoju wiedzy o PPP oraz dostosowywać swój udział w projektach do możliwości organizacyjno-finansowych. Zob. A. Borowiec, Partnerstwo publiczno-prywatne: zagrożenia i bariery stosowania w polskich przedsiębiorstwach w świetle badań empirycznych, ,Zeszyty Naukowe Politechniki Poznańskiej. Organizacja i Zarządzanie" 2017, nr 75, s. 77; A. Bleja, Partnerstwo publiczno-prywatne w administracji publicznej, „Acta Universitatis Lodziensis. Folia Oeconomica” 2010, nr 243, s. 57; E. Kraska, Wpływ władz samorzadowych na tworzenie i funkcjonowanie klastrów na przykładzie gmin województwa świętokrzyskiego, „Zarządzanie i Finanse” 2012, nr 1 (10), t. 2, s. 92.

35 Podstawowym obszarem specjalizacji klastra jest aktywny wypoczynek oraz połączenie turystycznej rekreacji i wypoczynku z organizacją imprez sportowych o zasięgu regionalnym i ogólnopolskim. Jego misją jest rozwój aktywnego wypoczynku i turystyki, propagowanie zdrowego stylu życia i promowanie walorów turystycznych Polski. Zob. http://klasteraktywnejturystyki.pl/partnerstwo-publiczno-prywatne-szansa-na-rozwoj-malopolskiej-turystyki (dostęp: 20.08.2018 r.).

36 Jednym z priorytetowych kierunków rozwoju turystyki w ciągu najbliższych lat jest realizacja inwestycji z wykorzystaniem formuły PPP, co znajduje swój wyraz w Programie Rozwoju Turystyki do roku 2020. W celu promocji idei PPP wyodrębniono na stronie internetowej Ministerstwa Sportu i Turystyki zakładkę dedykowaną PPP w turystyce, która zawiera m.in. bazę wiedzy na ten temat, regulacje prawne i podstawowe informacje o zrealizowanych projektach PPP w turystyce. PPP jest bardzo ważne dla realizacji zadań publicznych i zaspakajania potrzeb społeczeństwa, w tym finansowania rozwoju infrastruktury turystycznej i potencjału turystycznego w kraju. Zob. https://www.msit.gov.pl (dostęp: 20.08.2018 r.). 
łem przedstawiciela jednostki samorządu terytorialnego oraz partnera prywatnego wybranego projektu PPP. Wizyty studyjne sprzyjały nie tylko rozwojowi wiedzy o możliwości zastosowania tej formy partnerstwa w klastrze, nawiązywaniu relacji i wymianie doświadczeń w obszarze tworzenia sieci współpracy międzybranżowej i realizacji wspólnych inicjatyw na rzecz społeczności lokalnej, ale także wzmacnianiu przedsiębiorczości.

W 2018 roku w Śląskim Klastrze Transportu Miejskiego zorganizowano szkolenia z zakresu zasad realizacji przedsięwzięć w formule PPP, głównie z obszaru szeroko rozumianego budownictwa, turystyki, IT i zarządzania obiektami ${ }^{37}$. W trakcie szkoleń można było pozyskać praktyczną wiedzę o procedurze składania indywidualnych ofert na ogłoszone przez partnera publicznego postępowania o PPP, czy też o budowaniu konsorcjów.

W listopadzie 2013 roku Regionalna Izba Przemysłowo-Handlowa w Częstochowie jako instytucjonalny koordynator Regionalnego Częstochowskiego Klastra Budownictwa i Infrastruktury „Budosfera” przygotowała i upubliczniła zapytanie ofertowe, dotyczące opracowania analizy możliwości prowadzenia inicjatyw klastrowych w ramach PPP. Koordynator klastra wymagał przygotowania w terminie do stycznia 2014 roku pisemnego opracowania zawierającego zasady i procedury niezbędne do realizacji, finansowania i rozliczania projektów w formule PPP. Najkorzystniejszą ofertę pod względem ceny, w kwocie 17500 zł, złożyła lokalna Kancelaria Radców Prawnych „Dynastia”38. Działalność klastra skupiona jest na rozwoju i promowaniu wiedzy o nowych technologiach i innowacyjnych rozwiązaniach w szeroko rozumianej branży budowlanej oraz realizowaniu i koordynowaniu różnych inwestycji w ramach PPP, istotnych dla rozwoju społeczno-gospodarczego. Dzięki współpracy i wspólnemu wykorzystaniu strategicznego potencjału członków klastra możliwe będzie zapewnienie lepszej pozycji w negocjacjach i wspólne z partnerem publicznym realizowanie inwestycji kluczowych dla regionu.

Analiza wtórnych źródeł informacji dobitnie wykazała, że PPP jest przede wszystkim atrybutem klastrów energii. Potencjał tej formy partnerstwa strategicznego może być użyteczny w zakresie sprawnego rozwoju energetyki rozproszonej i wykorzystania odnawialnych źródeł energii na rzecz kształtowania bezpieczeństwa energetycznego oraz poprawy efektywności energetycznej w samorządach. Klastry energii, skupiające lokalne podmioty zajmujące się m.in. wytwarzaniem, konsumpcją, magazynowaniem i sprzedażą energii, umożliwiają racjonalne wykorzystanie zasobów w sposób przyjazny dla środowiska naturalnego. $\mathrm{W}$ tych klastrach realizacja wysokonakładowych inwestycji w infrastrukturę techniczną, wytwórczą i pomiarową wymaga zaangażowania kapitału prywatnego

37 Struktura klastra powstała w 2013 roku w odpowiedzi na wyzwania związane z potrzebami rozwoju transportu publicznego w województwie śląskim. Jego misja dotyczy dążenia do harmonijnego funkcjonowania zrównoważonego rozwoju systemów transportowych na obszarach zurbanizowanych w województwie śląskim. Przyjęto, że proces urzeczywistnienia misji wymaga m.in.: ścisłej współpracy podmiotów sektora biznesu i nauki z instytucjami otoczenia biznesu i jednostkami samorządu terytorialnego, kreowania nowych wyrobów i usług, pozyskiwania funduszy na rozwój klastra. Zob. http://klaster.crt.net.pl (dostęp: 20.08.2018 r.).

${ }^{38}$ Grupę inicjatorów powstania struktury klastrowej, poza koordynatorem klastra, tworzyły lokalne podmioty m.in.: Gmina Częstochowa, Politechnika Częstochowska, Wyższa Szkoła Zarządzania, Śląska Okręgowa Izba Inżynierów Budownictwa, Towarzystwo Naukowe Organizacji i Kierownictwa, Agencja Rozwoju Regionalnego. Zob. http://www.riph.czest.pl/klastry/budosfera/146-regionalny-czestochowski-klaster-budownictwa-i-infrastruktury (dostęp: 20.08.2018 r.). 
i konkretnych działań w ramach PPP ${ }^{39}$. Warto podkreślić, że prawnie uregulowana działalność klastrów energii jest promowana przez Ministerstwo Energii.

\section{POSTRZEGANIE IDEI PARTNERSTWA PUBLICZNO-PRYWATNEGO PRZEZ MENEDŻERÓW KLASTRÓW - WYNIKI BADAŃ WŁASNYCH}

Głównym celem badań empirycznych była ocena postrzegania przez menedżerów klastrów idei PPP i możliwości jej wykorzystania w ekosystemie klastra. Dla sprawnego zgromadzenia danych pierowotnych wykorzystano klasyczną metodę badań ankietowych. Podstawowym narzędziem badawczym był autorski kwestionariusz ankiety, specjalnie skonstruowany na potrzeby badań, który zawierał 12 pytań w części zasadniczej i 3 pytania w części metryczkowej. Poza jednym półotwartym pytaniem o kluczowe bariery rozwoju PPP w klastrze, większość pytań miało charakter zamknięty. Jednorazowe i bezpośrednie badania przeprowadzono na grupie 28 menedżerów polskich klastrów, których dobrano w sposób celowy (nielosowy i intencjonalny). Zastosowano taką metodę doboru próby badawczej, kierując się własną wiedzą ekspercką w zakresie klasteringu i praktycznym doświadczeniem respondentów w zarządzaniu klastrem. Realizacja badań pełnych w całej populacji (zbiorowości generalnej) klastrów funkcjonujących w Polsce była niemożliwa głównie ze względów czasowych, technicznych i finansowych ${ }^{40}$.

$\mathrm{W}$ procesie badawczym wpierw zrealizowano badania ankietowe audytoryjne, gdzie kwestionariusze ankiety przekazano bezpośrednio grupie 8 respondentów w trakcie sesji matchmakingowej, w ramach konferencji klastrowej ${ }^{41}$, która odbyła się w dniu 30 czerwca 2017 roku w Warszawie. Następnie przesłano kwestionariusze ankiety pocztą elektroniczną do pozostałych 20 respondentów. Ostatecznie uzyskano 28 kompletnych ankiet, z których dane pozwoliły na sformułowanie wniosków badawczych. W procesie wnioskowania użyteczne były trzy podstawowe profile z metryczki, które dotyczyły wielkości, wieku i zaawansowania technologicznego badanych klastrów.

${ }^{39}$ M. Sołtysik, K. Mucha-Kuś, R. Rogus, Klastry energii w osiaganiu samowystarczalności energetycznej gmin, „Zeszyty Naukowe Instytutu Gospodarki Surowcami Mineralnymi i Energią PAN" 2018, nr 102, s. 304.

${ }^{40}$ Liczebność populacji klastrów w Polsce określono na podstawie źródeł wtórnych. W trakcie ogólnopolskiej inwentaryzacji klastrów, przeprowadzonej przez PARP w 2015 roku, zidentyfikowano 134 klastry. Zob. G. Buczyńska, D. Frączek, P. Kryjom, Raport z inwentaryzacji klastrów w Polsce 2015, Warszawa 2016, s. 7.

${ }^{41}$ Konferencję nt. „Polityka klastrowa i współpraca klastrów w ramach państw V4+4” zorganizowało Ministerstwo Rozwoju. Jej celem była promocja i wymiana doświadczeń pomiędzy przedstawicielami klastrów z krajów Grupy Wyszehradzkiej oraz Bułgarii, Chorwacji, Rumunii i Słowenii. Podczas konferencji, w której uczestniczyło 300 osób, związanych z klasteringiem, zwrócono uwagę na znaczenie klastrów dla rozwoju współpracy lokalnej, wzmocnienia reindustrializacji, umiędzynarodowienia polskich przedsiębiorstw i wdrażania wyników prac $\mathrm{B}+\mathrm{R}$ oraz innowacji do gospodarki. Zaprezentowano przedsiębiorcze inicjatywy klastrowe, dobre praktyki klastrów oraz scharakteryzowano funkcje instrumentów publicznych, sprzyjających wzmocnieniu polityki klastrowej. Integralną częścią tej konferencji była sesja matchmakingowa, w trakcie której istniała możliwość bezpośrednich rozmów bilateralnych pomiędzy uczestnikami konferencji. 
Sposród 28 respondentów z 11 województw ${ }^{42}$, aż $43 \%$ z nich reprezentowało klastry zrzeszające do 50 członków. Z kolei $36 \%$ respondentów reprezentowało klastry, w których funkcjonuje od 50 do 100 członków. Pozostała część badanych zarządzała dużymi klastrami (powyżej 100 członków). Pod względem kategorii wieku klastrów, wyraźnie dominowali ilościowo (57\%) respondenci z klastrów, które funkcjonują nie mniej niż 5 lat i nie dłużej niż 10 lat. Pod względem dwóch pozostałych kategorii, tj. do 5 lat i powyżej 10 lat zidentyfikowano dwie grupy liczące po 6 respondentów. Uwzględniając ostatnie pytanie metryczkowe odnośnie zaawansowania technologicznego klastrów stwierdzono, że klastry wysokich i średnio wysokich technologii rezprezentowało po 11 respondentów, zaś klastry niskich technologii -6 respondentów (tabela 2).

Tabela 2. Charakterystyka klastrów reprezentowanych przez respondentów $(\mathrm{N}=28)$

\begin{tabular}{|c|c|c|c|}
\hline \multirow{2}{*}{ Rozmiar klastra } & do 50 członków & $50-100$ członków & powyżej 100 członków \\
\cline { 2 - 4 } & 12 & 10 & 6 \\
\hline \multirow{2}{*}{ Wiek klastra } & do 5 lat & $5-10$ lat & powyżej 10 lat \\
\cline { 2 - 4 } & 6 & 16 & 6 \\
\hline $\begin{array}{c}\text { Zaawansowanie } \\
\text { technologiczne } \\
\text { klastra }\end{array}$ & $\begin{array}{c}\text { zaawansowany } \\
\text { technologicznie }\end{array}$ & $\begin{array}{c}\text { średnio zaawansowany } \\
\text { technologicznie }\end{array}$ & $\begin{array}{c}\text { nisko zaawansowany } \\
\text { technologicznie }\end{array}$ \\
\cline { 2 - 4 } & 11 & 11 & 6 \\
\hline
\end{tabular}

Źródło: opracowanie własne.

W opinii większości badanych (93\%) formuła PPP w klastrze jest możliwa. Zdanie przeciwne wyraziło tylko dwóch respondentów. Na pytanie, czy PPP może wzmocnić rozwój klastra, w tym relacji firm z lokalną administracją samorządowową, nieco mniej niż poprzednio, bo $86 \%$ respondentów odpowiedziało twierdząco. Przeciwne zdanie miał tylko jeden respondent, który reprezentował klaster z liczbą członków z przedziału 50-100, funkcjonujący jako nisko zaawansowany technologicznie nie dłużej niż 5 lat. Z kolei trzech respondentów nie miało zdania na ten temat.

Większość respondentów (79\%) stwierdziła, że w okresie badań (czerwiec - lipiec 2017 roku) nie realizowano żadnych projektów w formule PPP w ich klastrze. W pięciu klastrach tego typu projekty realizowano, przy czym w dwóch klastrach znajdowały się one w fazie embrionalnej/eksperymentalnej, a w trzech pozostałych - w fazie wzrostu. Warto podkreślić, że sytuacja ta dotyczyła w zasadzie klastrów, które zrzeszały do 50 członków. Brak zdania na ten temat wyraził tylko jeden respondent.

Podobna sytuacja miała miejsce w kontekście pytania o realizację różnych projektów w formule PPP w okresie poprzedzającym badania ankietowe, tj. 2012-2016. I w tym przypadku zdecydowana większość respondentów (86\%) stwierdziła, że w ich klastrach nie realizowano tego typu projektów. Czterech respondentów odpowiedziało twierdząco na to pytanie, przy czym jeden z nich uznał, że partnerem prywatnym był koordynator i firmy klastrowe. Według kolejnych dwóch respondentów - partnerem prywatnym były tylko firmy klastrowe. Z kolei ostatni z tej grupy badanych wskazał na koordynatora klastra jako partnera prywatnego $\mathrm{w}$ formule PPP.

${ }^{42}$ Respondenci reprezentowali klastry zakorzenione w 11 województwach, tj. w: dolnośląskim, lubelskim, łódzkim, małopolskim, mazowieckim, podkarpackim, pomorskim, śląskim, świętokrzyskim, wielkopolskim i zachodniopomorskim. 
Większość badanych (61\%) uznała, że koordynator i przedsiębiorcy reprezentowanych przez nich klastrów wykazują realne zainteresowanie współpracą z lokalnym podmiotem publicznym (administracją samorządową) w formule PPP. Taką odpowiedź najczęściej wskazywali respondenci z średnio zaawansowanych technologicznie badanych klastrów dużych (powyżej 100 członków), których struktura ukonstytuowała się ponad 10 lat temu. W opinii dwóch respondentów tego typu partnerstwem strategicznym zainteresowane są tylko firmy klastrowe. Z kolei sześciu (21\%) respondentów uznało, że tylko koordynator klastra mógłby podjąć się realizacji projektów w formule PPP. Zdaniem pozostałych trzech ankietowanych w ich klastrach wysokich technologii, zrzeszających do 50 członków, koordynatorzy i firmy klastrowe nie wykazują realnego zainteresowania PPP.

Odpowiedzi badanych na pytanie, czy w regionach zakorzenienia reprezentowanych przez nich klastrów istnieje sprzyjający klimat dla PPP, były mocno zróżnicowane (wykres 1). $43 \%$ badanych uznało, że w ich regionie rzeczywiście istnieje sprzyjający klimat dla inwestycji w formule PPP. Zdanie przeciwne wyraziło, aż 57\% badanych. Na sprzyjający klimat dla PPP w regionie zakorzenienia klastra wskazywała większość respondentów z dużych klastrów zaawansowanych technologicznie, które funkcjonują ponad 10 lat. $\mathrm{Z}$ kolei menedżerowie reprezentujący klastry nisko zaawansowane technologicznie byli częściej przeciwnego zdania w tej kwestii. Opinie respondentów o braku sprzyjającego klimatu dla PPP w wielu regionach kraju tłumaczyć można m.in. tym, że w obecnej perspektywie finansowej (2014-2020) mocno ograniczono publiczne wsparcie klastrów. Władze publiczne w ramach polityki klastrowej miały skoncentrować się na wspieraniu rozwoju klastrów kluczowych o strategicznym znaczeniu dla gospodarki. Jednakże klastry te nie otrzymały dotychczas wymiernego i satysfakcjonującego wsparcia publicznego.

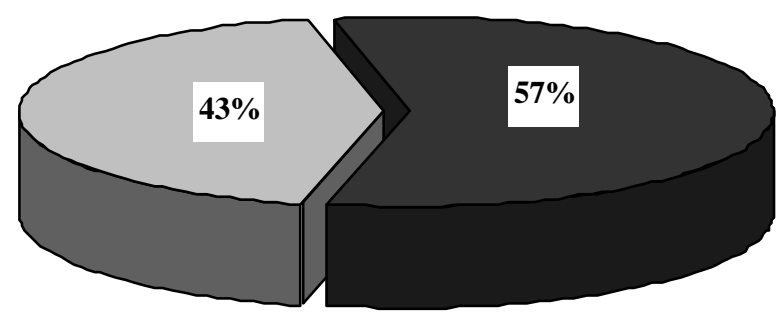

$\square$ sprzyjający klimat dla rozwoju PPP $\square$ niesprzyjający klimat dla rozwoju PPP

Wykres 1. Klimat dla rozwoju PPP w regionach zakorzenienia klastrów (N=28)

Źródło: opracowanie własne.

Z uwagi na zróżnicowanie badanych klastrów pod względem różnych kryteriów, w tym wielkości, wieku i zaawansowania technologicznego, reprezentujący je menedżerowie uznali, że przyszłe projekty $\mathrm{w}$ formule PPP firm klastrowych $\mathrm{z}$ lokalnym podmiotem publicznym mogłyby dotyczyć takich obszarów gospodarki komunalnej jak np.:

- usług społecznych, związanych z ochroną zdrowia, rozwojem sportu i rekreacji, bezpieczeństwem publicznym, kulturą i oświatą (20 wskazań);

- usług technicznych, związanych z zaopatrzeniem w energię elektryczną i ciepło (8 wskazań); 
- gospodarki odpadami, w tym składowania, utylizacji i recyklingu (8 wskazań);

- transportu publicznego i infrastruktury transportowej (6 wskazań);

- gospodarowania terenami zielonymi (4 wskazania);

- gospodarki wodnej, w tym usług wodno-kanalizacyjnych (1 wskazanie).

Należy w tym miejscu dodać, że respondenci w ramach pytania o potencjalny obszar przyszłego PPP mogli wskazać dwie odpowiedzi. Uzyskane wyniki jednoznacznie wykazują, że w większości badanych klastrów tym obszarem są usługi społeczne. Ten interdyscyplinarny obszar gospodarki komunalnej stwarza możliwość zaangażowania się szerokiemu gronu partnerów klastrowych w realizację konkretnych i wartościowych projektów infrastrukturalno-rozwojowych. Być może w ten właśnie sposób powstaną pożądane innowacje społeczne, w odpowiedzi na obecne i przyszłe potrzeby społeczne.

Większość respondentów (68\%), bazując na doświadczeniu w zarządzaniu klastrem uznała, że lokalny partner publiczny nie informuje koordynatora klastra i firmy klastrowe o potencjale PPP i możliwości nawiązania tego typu partnerstwa. Pozostałych dziewięciu respondentów miało odmienne zdanie na ten temat. Pięciu respondentów (18\%) oceniło tę aktywność lokalnych organizacji publicznych na poziomie średnim, trzech respondentów na poziomie bardzo niskim, a jeden respondent - na poziomie niskim. Średnia ocen na poziomie $2,2 \mathrm{w}$ pięciostopniowej skali świadczy o niskim poziomie zaangażowania potencjalnych lokalnych partnerów publicznych na rzecz propagowania wiedzy o PPP i stymulowania klastrów do realizacji inwestycji w tej formule partnerstwa.

$\mathrm{W}$ trakcie badań ankietowych respondenci wskazali także na kluczowe bariery rozwoju PPP w ich klastrach (tabela 3). W tym przypadku uzyskane odpowiedzi były mocno zróżnicowane, co świadczy o tym, że nie ma uniwersalnego kanonu tego typu barier.

Tabela 3. Kluczowe bariery rozwoju PPP w badanych klastrach $(\mathrm{N}=28)$

\begin{tabular}{|c|l|c|}
\hline Lp. & \multicolumn{1}{|c|}{ Bariery } & Liczba wskazań \\
\hline B1 & $\begin{array}{l}\text { Niska świadomość i niewystarczająca wiedza o PPP w sektorze } \\
\text { publicznym. }\end{array}$ & 12 \\
\hline B2 & $\begin{array}{l}\text { Brak informacji od partnera publicznego o możliwości realizacji } \\
\text { inwestycji w formule PPP. }\end{array}$ & 12 \\
\hline B3 & Niska świadomość i niewystarczająca wiedza o PPP w klastrze & 8 \\
\hline B4 & ryzyko podejrzeń o charakterze korupcyjnym. & 5 \\
\hline B5 & $\begin{array}{l}\text { Negatywna opinia o dotychczasowej współpracy z administracją } \\
\text { samorządową. }\end{array}$ & 4 \\
\hline B6 & Uregulowania prawne PPP. & 4 \\
\hline B7 & Podział zadań i wysokie ryzyko inwestycyjne. & 4 \\
\hline B8 & $\begin{array}{l}\text { Brak wykwalifikowanej kadry u partnera publicznego do wdrażania } \\
\text { przedsięwzięć w formule PPP. }\end{array}$ & 3 \\
\hline B9 & $\begin{array}{l}\text { Brak wykwalifikowanej kadry w klastrze do wdrażania przedsię- } \\
\text { wzięć w formule PPP. }\end{array}$ & 1 \\
\hline B10 & Procedura wyboru partnera prywatnego. & 1 \\
\hline B11 & $\begin{array}{l}\text { Rentowność realizowanych projektów i zysk dla firm klastrowych } \\
\text { w formule PPP. }\end{array}$ & 1 \\
\hline
\end{tabular}

Uwaga: respondenci mogli wskazać maksymalnie dwie odpowiedzi.

Źródło: opracowanie własne. 
Dla 43\% respondentów kluczowymi barierami rozwoju PPP były: niska świadomość i niewystarczająca wiedza o PPP w sektorze publicznym oraz brak informacji od partnera publicznego o możliwości realizacji inwestycji w tej formule partnerstwa strategicznego.

Na podstawie danych zamieszczonych w tabeli 3 można wnioskować, że dla eliminowania barier rozwoju PPP w polskich klastrach niezbędne są po pierwsze aktywne działania na rzecz rozwoju wiedzy o PPP wśród pracowników administracji publicznej na poziomie lokalnym, regionalnym i centralnym, a po drugie niezbędna jest większa otwartość partnerów publicznych na realizację inwestycji publicznych $\mathrm{w}$ formule PPP $\mathrm{z}$ koordynatorami i członkami klastrów oraz sprawna komunikacja marketingowa w tym obszarze. W tym miejscu należy podkreślić, że Ministerstwo Inwestycji i Rozwoju, mając na uwadze te i inne bariery rozwoju PPP w Polsce, od czerwca 2016 roku do listopada 2019 roku realizuje projekt „Rozwój PPP w Polsce” wraz z partnerami, skoncentrowany na doskonaleniu kompetencji m.in. pracowników jednostek samorządu terytorialnego i jednostek podległych. Być może zorganizowane w ramach projektu szkolenia w miastach wojewódzkich i inne edukacyjne wydarzenia im towarzyszące pozytywnie wpłyną na stopniowe eliminowanie kluczowych barier rozwoju PPP w klastrach, szczególnie tych wskazanych przez respondentów. Oczywiście strategiczne znaczenie w tym obszarze mają nowe regulacje prawne, w tym znowelizowana ustawa o PPP z lipca 2018 roku.

Wachlarz korzyści, jakich może dostarczyć realizacja projektów w ramach PPP w badanych klastrach jest bardzo szeroki (tabela 4). Według ankietowanych do kluczowych potencjalnych korzyści w tym obszarze, które jednocześnie mogą okazać się wartościowe dla partnera publicznego i partnera prywatnego, zaliczyć można m.in.: rozwój lokalny, transfer technologii i know-how, dzielenie się wiedzą i doświadczeniem partnerów.

Tabela 4. Potencjalne obopólne korzyści z realizacji PPP w badanych klastrach $(\mathrm{N}=28)$

\begin{tabular}{|c|l|c|}
\hline Lp. & \multicolumn{1}{|c|}{ Korzyści } & Liczba wskazań \\
\hline K1 & Rozwój lokalny. & 13 \\
\hline K2 & $\begin{array}{l}\text { Transfer technologii i know-how, dzielenie się wiedzą i doświadcze- } \\
\text { niem partnerów. }\end{array}$ & 12 \\
\hline K3 & $\begin{array}{l}\text { Efektywne wykorzystanie zasobów i obniżenie całkowitych kosz- } \\
\text { tów wspólnie realizowanego projektu. }\end{array}$ & 8 \\
\hline K4 & Przyspieszenie procesów inwestycyjnych. & 7 \\
\hline K5 & Sprawna realizacja innowacyjnych projektów. & 5 \\
\hline K6 & Efektywne zarządzanie środkami publicznymi. & 4 \\
\hline K7 & Podział ryzyka pomiędzy partnerami. & 3 \\
\hline K8 & $\begin{array}{l}\text { Wysoka jakość publicznej infrastruktury technicznej uzyskana } \\
\text { w najkrótszym czasie. }\end{array}$ & 2 \\
\hline K9 & Wysoka jakość świadczonych usług publicznych. & 2 \\
\hline
\end{tabular}

Uwaga: respondenci mogli wskazać maksymalnie dwie odpowiedzi.

Źródło: opracowanie własne.

Z danych zamieszczonych $\mathrm{w}$ tabeli 4 wynika, że respondenci nie byli jednomyślni w badanej kwestii. Wskazany rozwój lokalny, jako kluczowa obopólna korzyść z realizacji PPP w klastrach, związany jest bezpośrednio z lokalną działalnością klastrów. Nie bez 
znaczenia jest fakt, że wskazana kolejna kluczowa korzyść przejawiająca się w transferze technologii i know-how oraz dzieleniu się wiedzą i doświadczeniem partnerów, w znacznym stopniu determinuje uprzednio wymieniony rozwój lokalny.

W trakcie badań zapytano także respondentów o aktywność koordynatorów klastrów w zakresie wykorzystania różnych form rozwoju wiedzy o potencjale PPP i możliwościach realizacji projektów inwestycyjnych z lokalnym partnerem publicznym. Należy podkreślić, że w opinii zdecydowanej większości respondentów (86\%) w ich klastrach koordynator dotychczas nie wykazywał się taką aktywnością. Zaledwie tylko czerech respondentów potwierdziło, że koordynator podejmował konkretne tego typu działania edukacyjno-informacyjne, gdzie w dwóch klastrach skupiających od 50 do 100 członków - raz w roku, w jednym klastrze zaawansowanym technologicznie - raz na kwartał i w jednym klastrze średnio wysokich technologii - więcej niż cztery razy w roku.

Ostatnie zamknięte pytanie zamieszczone w części zasadniczej ankiety dotyczyło potencjalnego zapotrzebowania koordynatorów badanych klastrów na wsparcie firm doradczych w zakresie formalnej procedury i implementacji PPP. I tym razem, po raz kolejny respondenci nie byli jednomyślni w badanej kwestii. 64\% respondentów uznało, że koordynatorzy reprezentowanych przez nich klastrów rzeczywiście potrzebują i oczekują tego typu wsparcia firm doradczych. Pozostała część respondentów miała odmienne zdanie w tej kwestii (wykres 2).

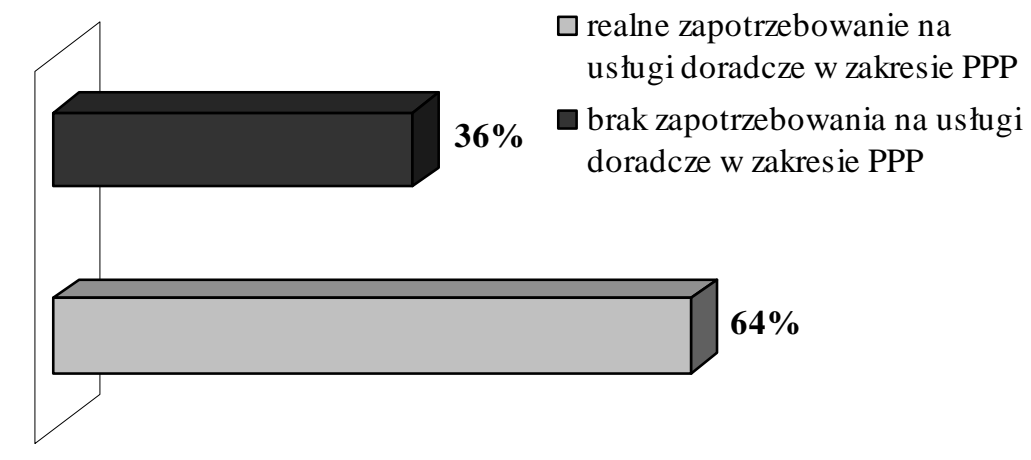

Wykres 2. Zapotrzebowanie koordynatorów badanych klastrów na usługi firm doradczych w zakresie PPP $(\mathrm{N}=28)$

Źródło: opracowanie własne.

Na podstawie uzyskanych odpowiedzi respondentów odnośnie do wsparcia firm doradczych w zakresie PPP stwierdzono, że:

- potrzebują i oczekują tego wsparcia głównie koordynatorzy nisko zaawansowanych technologicznie klastrów dużych (powyżej 100 członków), zarówno tych, które funkcjonują na rynku ponad 10 lat, jak i tych, których struktura ukonstytuowała się nie dawniej niż 5 lat temu;

- nie potrzebują tego wsparcia głównie koordynatorzy zaawansowanych technologicznie klastrów, zrzeszających do 50 członków, działających nie dłużej niż 10 lat. 
Kompleksowa współpraca koordynatora klastra z firmą doradczą w różnej formie i zakresie może sprzyjać sprawnej analizie atrakcyjności tej formy partnerstwa dla rozwoju klastra. Ponadto może pozwolić na poprawną ocenę potencjału strategicznego klastra i partnera publicznego w kontekście realizacji złożonych i długoterminowych projektów infrastrukturalno-rozwojowych. Aby zoptymalizować pozytywne efekty współpracy z firmą doradczą nie bez znaczenia jest sam jej wybór. Co prawda tego typu firm na rynku jest bardzo dużo, jednakże nie każda z nich oferuje wysoką jakość usług i nie każda ma wymagane doświadczenie odnośnie projektów w modelu PPP na polskim rynku. W tym przypadku celowe byłoby bezpłatne doradztwo prawne, finansowe i techniczne dla koordynatorów klastrów oferowane w ramach krajowej i regionalnej polityki klastrowej, na podobnych zasadach jak to, które przygotowało Ministerstwo Inwestycji i Rozwoju dla organizacji publicznych $^{43}$. W lepszej sytuacji znajdują się te klastry, których koordynatorzy i członkowie są aktywni projektowo, mają dostęp do dobrych praktyk w tym obszarze i korzystają ze wsparcia doradców, którzy są ich stałymi partnerami biznesowymi.

\section{ZAKOŃCZENIE}

Realizacja inwestycji z partnerem publicznym w różnej skali i o różnym zakresie stanowi istotne wyzwanie strategiczne w zarządzaniu klastrem. Jest to związane chociażby z kształtowaniem świadomości społeczności klastrowej o tej formie inwestycji i racjonalnym wykorzystaniem potencjału partnera publicznego w kontekście tworzenia wartości w klastrze. Bez wątpienia, w tym konkretnym przypadku, dążenie do optymalizacji wartości ekonomicznych nie stoi w sprzeczności z optymalizacją wartości społecznych.

Obecne uwarunkowania coraz bardziej sprzyjają realizacji publicznych projektów infrastrukturalno-rozwojowych w ekosystemie klastrów. Liczne zmiany regulacji prawnych w zakresie PPP, uruchomiona platforma PPP jako forum wymiany informacji i dobrych praktyk o realizacji konkretnych projektów, przygotowywane opisy dobrych praktyk i wzory umów dla obniżenia kosztów tych projektów, to tylko wybrane przykłady działań, które świadczą o realnym zaangażowaniu władz publicznych we wdrażanie polityki rozwoju PPP w Polsce. Wraz z upowszechnieniem wiedzy i kompetentnym przygotowaniem administracji publicznej w zakresie PPP wzrasta szansa na skuteczną realizację projektów $\mathrm{w}$ tej formule.

Przeprowadzone badania empiryczne nie tylko potwierdziły stan wiedzy teoretycznej o PPP w klastrach, ale także uzupełniły ten obszar wiedzy. Na podstawie uzyskanych jednomyślnych opinii większości respondentów stwierdzono bowiem, że:

- podobnie jak w okresie 2012-2016, tak i w okresie badań ankietowych nie realizowano w badanych klastrach projektów w formule PPP;

\footnotetext{
${ }^{43}$ Należy podkreślić, że Ministerstwo Inwestycji i Rozwoju oferuje bezpłatne doradztwo prawne, finansowe i techniczne na wysokim eksperckim poziomie dla organizacji publicznych, które chcą realizować inwestycje w formule PPP. W grudniu 2016 r. uruchomiono specjalny nabór wniosków, przez co zewnętrzni eksperci pomagają obecnie przy siedmiu projektach z zakresu infrastruktury transportowej, efektywności energetycznej i budowy obiektów użyteczności publicznej. W styczniu $2017 \mathrm{r}$. podpisano umowy ramowe o wartości $12 \mathrm{mln}$ zł z trzema konsorcjami firm doradczych na świadczenie kompleksowego doradztwa dla podmiotów publicznych. Zob. https://www. miir.gov.pl/strony/zadania/partnerstwo-publiczno-prywatne (dostęp: 20.08.2018 r.).
} 
- dotychczasowymi barierami kluczowymi rozwoju PPP w badanych klastrach były m.in. niska świadomość i niewystarczająca wiedza o PPP w sektorze publicznym oraz brak informacji od partnera publicznego o możliwości realizacji PPP;

- dotychczas lokalny partner publiczny nie informował koordynatorów i firmy badanych klastrów o potencjale PPP i możliwości nawiązania współpracy;

- nie tylko organizacje publiczne, ale także instytucjonalni koordynatorzy badanych klastrów dotychczas nie propagowali i rozwijali wiedzy społeczności klastrowej o potencjale PPP i różnych możliwościach współpracy z partnerem publicznym;

- koordynatorzy i członkowie badanych klastrów wykazywali realne zainteresowanie realizacją projektów infrastrukturalno-rozwojowych w formule PPP pomimo tego, że w regionach ich zakorzenienia brakowało dotychczas sprzyjającego klimatu dla rozwoju tego typu partnerstwa strategicznego;

- PPP w badanych klastrach mogłoby w przyszłości dotyczyć przede wszystkim usług społecznych w ramach gospodarki komunalnej;

- możliwa jest implementacja PPP w ekosystemie klastrów, która sprzyja osiąganiu korzyści dla partnera prywatnego i publicznego odnośnie m.in. rozwoju lokalnego, transferu technologii i know-how, dzielenia się wiedzą i doświadczeniem;

- PPP może wzmocnić rozwój klastra i jakość jego relacji z partnerem publicznym;

- koordynatorzy badanych klastrów potrzebują wsparcia firm doradczych w zakresie implementacji PPP (np. przy opracowaniu dokumentacji przedrealizacyjnej, ocenie własnego potencjału strategicznego i potencjalnego ryzyka inwestycyjnego, wyborze korzystnej oferty partnera publicznego).

Zamiarem autora artykułu było uwzględnienie jak najszerszego spektrum analizy PPP w klastrach. Jednakże z uwagi na fakt, że jest to trudny i rozległy obszar badawczy, tym samym wymaga dalszych pogłębionych badań o charakterze jakościowym i ilościowym. Zaprezentowane $\mathrm{w}$ artykule praktyczne i teoretyczne rozważania mogą być inspiracją dla społeczności klastrowej i badaczy zajmujących się problematyką klasteringu w Polsce.

\section{LITERATURA}

1. Augustyńska B., Koncepcja partnerstwa publiczno-prywatnego na przykładzie Holandii, „Zarządzanie Publiczne” 2007, nr 3.

2. Bernatowicz Ł, Partnerstwo publiczno-prywatne z punktu widzenia doświadczeń strony prywatnej, ,Studia BAS” 2014, nr 3 (39).

3. Bleja A., Partnerstwo publiczno-prywatne w administracji publicznej, „Acta Universitatis Lodziensis. Folia Oeconomica" 2010, nr 243.

4. Blicharz P., Skowron S., Kapitat intelektualny jako czynnik rozwoju partnerstwa publiczno-prywatnego, Politechnika Lubelska, Lublin 2013.

5. Bodzoń K., Funkcjonowanie partnerstwa publiczno-prywatnego w ramach realizacji projektów inwestycyjnych, „Przegląd Administracji Publicznej” 2013, nr 1.

6. Borowiec A., Możliwości budowy sieci gospodarczych na bazie partnerstwa publiczno-prywatnego w świetle badań empirycznych, ,Zeszyty Naukowe Uniwersytetu Szczecińskiego. Finanse, Rynki Finansowe, Ubezpieczenia” 2011, nr 687 (48). 
7. Borowiec A., Partnerstwo publiczno-prywatne: zagrożenia i bariery stosowania w polskich przedsiębiorstwach $w$ świetle badań empirycznych, ,Zeszyty Naukowe Politechniki Poznańskiej. Organizacja i Zarządzanie" 2017, nr 75.

8. Borowski K., Dotychczasowe doświadczenia i możliwości implementacji partnerstwa publiczno-prywatnego przez jednostki samorzadu terytorialnego w Polsce, „Ekonomiczne Problemy Usług" 2016, nr 125.

9. Buczyńska G., Frączek D., Kryjom P., Raport z inwentaryzacji klastrów w Polsce 2015, PARP, Warszawa 2016.

10. Brzozowska K., Innowacyjność partnerstwa publiczno-prywatnego w polityce inwestycyjnej jednostek sektora publicznego w Polsce, „Folia Pomeranae Universitatis Technologiae Stetinensis. Oeconomica” 2011, nr 291 (65).

11. Bucka M., Wsparcie rozwoju klastrów w Polsce $w$ perspektywie finansowej 2014-2020, „Prace Naukowe Uniwersytetu Ekonomicznego we Wrocławiu” 2017, nr 466.

12. Derlukiewicz N., Mempel-Śnieżyk A., Realizacja inwestycji w formie partnerstwa publiczno-prywatnego - aspekt teoretyczny, „Prace Naukowe Uniwersytetu Ekonomicznego we Wrocławiu" 2016, nr 443.

13. Hajdys D.M., Uwarunkowania partnerstwa publiczno-prywatnego w finansowaniu inwestycji jednostek samorzadu terytorialnego, Wydawnictwo Uniwersytetu Łódzkiego, Łódź 2013.

14. Kania M., Partnerstwo publiczno-prywatne jako forma realizacji zadań jednostek samorzadu terytorialnego, ,Zeszyty Myszkowskie” 2015, $\mathrm{nr} 2$.

15. Knop L., Zarzadzanie klastrem: koncepcje, strategie, modele, Wydawnictwo Politechniki Śląskiej, Gliwice 2013.

16. Kołodziej-Hajdo M., Partnerstwo publiczno-prywatne jako narzędzie nowoczesnego zarzqdzania organizacjami publicznymi, ,Studia Ekonomiczne. Zeszyty Naukowe Uniwersytetu Ekonomicznego w Katowicach” 2015, nr 224.

17. Korbus B., Srokosz T., Wawrzyniak M., Partnerstwo publiczno-prywatne: poradnik, Urząd Zamówień Publicznych, Warszawa 2010.

18. Kraska E., Wptyw władz samorządowych na tworzenie i funkcjonowanie klastrów na przykładzie gmin województwa świętokrzyskiego, ,Zarządzanie i Finanse” 2012, nr 1 (10), t. 2.

19. Lisowska A., Rubisz Sz., Sektor instytucji publicznych a rozwój klastrów w województwie opolskim, Wyższa Szkoła Zarządzania i Administracji w Opolu, Opole 2011.

20. Łukomska-Szarek J., Włóka M., Partnerstwo publiczno-prywatne w procesie rozwoju samorząów lokalnych, „Zeszyty Naukowe Uniwersytetu Szczecińskiego. Finanse, Rynki Finansowe, Ubezpieczenia” 2014, nr 804 (67).

21. Nowicki H., Nowicki P., Partnerstwo publiczno-prywatne jako element systemu zamówień publicznych, "Studia BAS" 2014, nr 3 (39).

22. Paczoski A., Reguty oraz znaczenie partnerstwa publiczno-prywatnego dla funkcjonowania przedsiębiorstw, „Zarządzanie i Finanse” 2012, nr 1, t. 10, cz. 3.

23. Piątyszek-Pych A., Rola samorzadu terytorialnego w realizacji polityki rozwoju opartej na klastrach, „Zeszyty Naukowe Uniwersytetu Szczecińskiego. Finanse, Rynki Finansowe, Ubezpieczenia” 2013, nr 786 (64/2).

24. Płaczek E., Rozwój logistyki społecznej poprzez partnerstwo publiczno-prywatne, „Zeszyty Naukowe Politechniki Częstochowskiej. Zarządzanie” 2017, nr 25, t. 2.

25. Sikora E., Partnerstwo publiczno-prywatne w zarzadzaniu Gmina Bytom, „Zeszyty Naukowe Politechniki Częstochowskiej. Zarządzanie” 2017, nr 25, t. 2. 
26. Skica T., Dzyuma-Zaremba U., Hady J., Klastry w polityce regionalnej, „Barometr Regionalny" 2015, nr 2 (13).

27. Smalec A., Znaczenie partnerstwa publiczno-prywatnego dla rozwoju regionu, „Zeszyty Naukowe Uniwersytetu Szczecińskiego. Ekonomiczne Problemy Usług” 2011, nr 682 (76).

28. Sołtysik M, Mucha-Kuś K., Rogus R., Klastry energii w osiaganiu samowystarczalności energetycznej gmin, ,Zeszyty Naukowe Instytutu Gospodarki Surowcami Mineralnymi i Energią PAN" 2018, nr 102.

29. Spigel B., Harrison R., Toward a process theory of entrepreneurial ecosystems, „Strategic Entrepreneurship Journal” 2018, nr 12.

30. Szafran J., Projekty hybrydowe - montaż partnerstwa publiczno-prywatnego i funduszy Unii Europejskiej w projektach rozwoju lokalnego i regionalnego, „Barometr Regionalny” 2017, nr 4 (15).

31. Szymański K., Korbus B., Analiza rynku PPP za okres od 2009 roku do 30 czerwca 2018 roku, Instytut Partnerstwa Publiczno-Prywatnego, Warszawa 2018.

32. Śmiechowicz J., Partnerstwo publiczno-prywatne w sektorze dróg - ocena dotychczasowych doświadczeń i możliwości implementacji przez samorzad terytorialny w Polsce, „Prace Naukowe Uniwersytetu Ekonomicznego we Wrocławiu” 2015, nr 404.

33. Tuziak A., Klastry jako stymulatory rozwoju regionalnego, „Nierówności Społeczne a Wzrost Gospodarczy” 2018, nr 54 (2).

34. Włodarczyk B., Ekonomiczne i prawne bariery rozwoju partnerstwa publiczno-prywatnego w Polsce, „Optimum. Studia Ekonomiczne” 2013, nr 1 (61).

35. Zalewski D., PPP z wykorzystaniem środków krajowych, „Biuletyn Partnerstwa Publiczno-Prywatnego" 2018, nr 4.

\section{PRAWODAWSTWO}

Ustawa z dnia 5 lipca 2018 r. o zmianie ustawy o partnerstwie publiczno-prywatnym oraz niektórych innych ustaw (Dz.U. z 2018 r., poz. 1693).

Ustawa z dnia 19 grudnia 2008 r. o partnerstwie publiczno-prywatnym (Dz.U. z 2009 r., nr 19, poz. 100).

Uchwała nr 116/2017 Rady Ministrów z dnia 26 lipca 2017 roku w sprawie przyjęcia dokumentu „Polityka Rządu w zakresie rozwoju partnerstwa publiczno-prywatnego”.

\section{NETOGRAFIA}

1. https://www.ppp.gov.pl/projekt-rozwoju-PPP/Strony/Oprojekcie.aspx (dostęp: 20.08.2018 r.).

2. https://www.ppp.gov.pl/baza/Strony/baza_projektow_ppp.aspx (dostęp: 20.08.2018 r.).

3. https://www.miir.gov.pl/strony/aktualnosci/sejm-przyjal-nowelizacje-ustawy-o-ppp (dostęp: 20.08.2018 r.).

4. https://www.miir.gov.pl/strony/zadania/partnerstwo-publiczno-prywatne (dostęp: 20.08 . 2018 r.).

5. https://www.msit.gov.pl/pl/turystyka/ppp-w-turystyce/3459,PPP-W-TURYSTYCE.html (dostęp: 20.08.2018 r.).

6. http://klaster.crt.net.pl (dostęp: 20.08.2018 r.). 


\section{PUBLIC-PRIVATE PARTNERSHIP AS A STRATEGIC CHALLENGE IN CLUSTER MANAGEMENT}

The article focuses on a contemporary approach to a complex and multifaceted problem of public-private partnership (PPP) inside a cluster's ecosystem whose boundaries are highly variable. The basis for the considerations and conclusions formulated in the article are not only the results of empirical research conducted by means of a survey of a deliberately selected sample of 28 managers of Polish clusters, but also literature review and desk research. A practical approach to the research problem is supported by selected experiences and good practices of clusters. The article consists of three parts, in which the essence and main assumptions of the PPP concept, its significance for the development of clustering, and its perception by cluster managers are characterized in a synthetic way. Basing on the literature review, it has been shown that efficient use of the potential of PPP poses a strategic challenge to cluster coordinators, among others, in the area of shaping relations with public partners and securing sources of financing for this type of projects. Financing investments from domestic and foreign funds may be conducive to both the construction and modernization of municipal infrastructure and the development of clusters. In particular, hybrid projects, where the PPP formula is co-financed by the European Union, enable the implementation of large infrastructure projects that meet social needs. In this case, the institutional coordinator and cluster members can act as a private partner, being an investor, general contractor or subcontractor. The results of empirical research presented in the article prove that in the majority of surveyed clusters no projects in the PPP formula have been implemented so far. Nevertheless, it is very optimistic that coordinators and members of these clusters show a real interest in this type of strategic partnership, although there is still a lack of favorable climate for its implementation in many regions of the country.

Keywords: cluster, management, public-private partnership, development.

DOI: $10.7862 /$ rz.2018.mmr.21

Tekst ztożono do redakcji: sierpień 2018 r.

Tekst przyjęto do druku: wrzesień 2018 r. 